\title{
FACTOR INFLUENCING THE SPATIO-TEMPOARAL DISTRIBUTION OF ZOOPLANKTON BIOMASS IN THE MERBOK ESTUARY, MALAYSIA
}

\author{
Kaniz Fatema*, Wan Maznah Wan Omar ${ }^{1}$, Mansor Mat Isa ${ }^{1}$ \\ and Md. Omar Ahmad ${ }^{1}$ \\ Department of Fisheries, University of Dhaka, Dhaka 1000, Bangladesh
}

\begin{abstract}
Spatial and temporal distribution of zooplankton biomass in the Merbok estuary were studied. Zooplankton samples were collected monthly from January to December 2011 at six sampling stations along the river stretch by using $0.13 \mathrm{~m}$ diameter plankton net (150 $\mu \mathrm{m}$ mesh size) in horizontal towing. Average zooplankton biomass ranged from 0.1143 to $1.8217 \mathrm{~g}$ dry wt. $\mathrm{m}^{-3}$. The maximum and minimum zooplankton biomass recorded in February and October 2011, respectively. The highest zooplankton biomass was found at Station 6 (downstream) and the lowest in Station 1 (upstream). Zooplankton biomass varied from upstream to downstream. Kruskal-Wallis $\mathrm{H}$ test showed that distribution of zooplankton biomass among the sampling months was significantly different $(\mathrm{p}<$ 0.05). Spearman's rank correlation analysis revealed significant correlation among zooplankton biomass, chl $a$ concentration and nutrients $(\mathrm{p}<0.01)$.
\end{abstract}

Key words: Zooplankton biomass, distribution, Merbok estuary

\section{INTRODUCTION}

Zooplankton biomass is essential for estimation of secondary production and fishery potential of a water body (Wickstead 1965, Rezai et al. 2003, Sahu et al. 2012). The Merbok estuary is a mangrove estuary. It is located in the north-west Peninsular Malaysia and flows into the Straits of Malacca after passing through paddy fields on its fresh-water route and mangroves on its estuarine route. The estuary is connected to the Muda river in the south through a channel. Average water discharge of Muda river is around $100 \mathrm{~m}^{3} \mathrm{sec}$-1(DID 1974). This estuary is great source of fisheries and local people are dependent on the Merbok River for their livelihood by fishing (Isa et al. 2012, Kaniz et al. 2012, 2013, 2015). However, a few researches have been carried out on zooplankton biomass in Malaysia (Rezai et al. 2003, Sahu et al. 2012). Therefore, the present study was undertaken to observe the temporal and spatial distribution of zooplankton biomass in the Merbok estuary in relation to its water quality parameters.

\section{MATERIAL AND METHODS}

Zooplankton samples were collected at monthly interval from January to December, 2011 at six sampling stations in the Merbok estuary. Horizontal

*Corresponding author: f.kaniz@yahoo.com. ${ }^{1}$ School of Biological Sciences, Universiti Sains Malaysia, 11800 Penang, Malaysia. Center for Marine and Coastal Studies (CEMACS), Universiti Sains Malaysia, 11800 Penang, Malaysia

다 2016 Zoological Society of Bangladesh DOI: 10.3329/bjz.v44i1.30184 
towing method was used to collect zooplankton samples from surface water of each sampling station. Towing was done for 18 minutes by plankton net of 0.13 $\mathrm{m}$ dia, made up of bolting silk (mesh size $150 \mu \mathrm{m}$ ). After collection, the samples were immediately preserved in $4 \%$ buffered formalin and used for quantitative and qualitative analysis. The total zooplankton biomass was estimated as dry weight (Harris 2000). Zooplankton samples were oven dried at $105^{\circ} \mathrm{C}$ for $24 \mathrm{hrs}$ at each sampling station. Then weighted by an electronic balance to determine total dry weight of biomass. Results were recorded as g dry wt. $\mathrm{m}^{-3}$. Rainfall data were collected from the meteorological Department of Kedah, Malaysia. Water temperature and salinity were made by using Hydro lab Surveyor 3 Data Logger. Chlorophyll a concentration was determined according to the Strickland and Parsons (1972). Nitrite and nitrate concentration were measured by using the

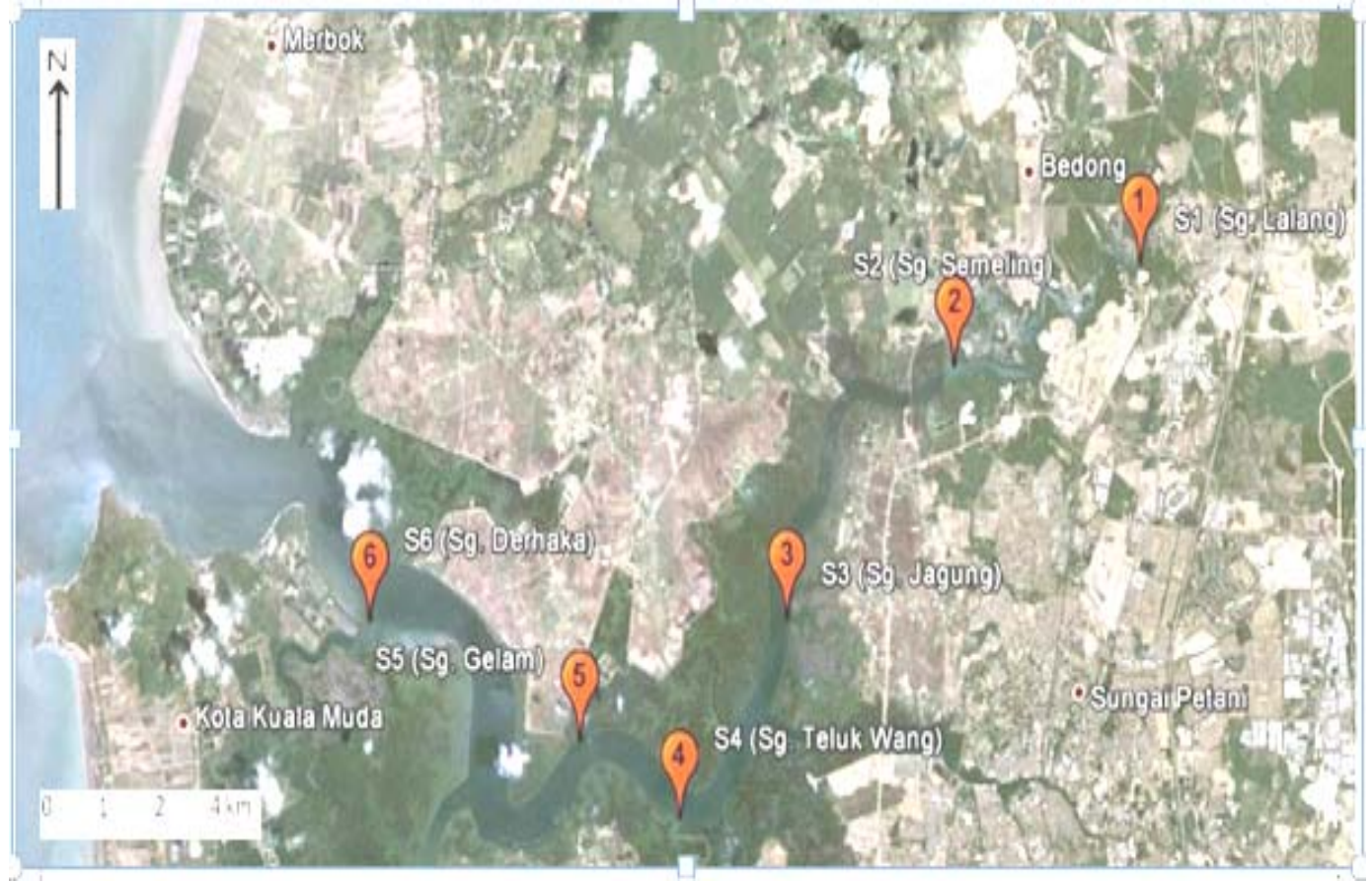

Fig. 1. Merbok estuary (Source: google map).

calorimetric method and the cadmium reduction method (APHA 1991). The concentration of ammonia-N was determined using the ammonia low-level indophenol method (Adams 1991). Considering human activities such as agriculture, aquaculture, and land development six sampling stations were selected for this study. Station 1 (Lalang River) and 2 (Semeling River) were located on the upper reaches of the estuary while Station 3 (Jagung River) and 4 (Teluk Wang) at the middle, and Station 5 (Gelam River) and 6 (Derhaka River) were on the downstream (Fig. 1). 
To observe the significant difference of spatial and temporal distribution of zooplankton biomass nonparametric tests (Kruskal-Wallis H test, Mann-Whitney U test) and Spearman's rank correlation were performed.

\section{RESULTS AND DISCUSSION}

Temperature, salinity, chlorophyll a and nutrients: Temperature did not show any significant differences between the sampling stations and month. Average temperature varied from 27 to $30.90^{\circ} \mathrm{C}$ within 12 months period. The maximum temperature was found at Station 1 (upstream) whereas, minimum at the Station 5. Salinity values ranged from 5.20 to $35.10 \mathrm{ppt}$. The maximum average salinity recorded at the Station 5 and the minimum at Station 1. In Merbok estuary, temperature fluctuations are insignificant among the months and stations. However, salinity concentration varied significantly among the months and stations. Therefore, higher zooplankton biomass in down streams may be due to high salinity of the downstream. According to Wooldridge (1999) interactive effects of temperature and salinity influences zooplankton composition and biomass in estuaries. Other studies also confirmed linear relationship between temperature and zooplankton biomass (Jerling and Wooldridge 1991, Grange and Allanson 1995). The chlorophyll $a$ concentration varied from 0.1 to 5.24 $\mu \mathrm{g} / 1$ with a mean average value of $0.549 \pm 0.50 \mu \mathrm{g} / 1$. Highest chlorophyll $a$ was found in the upstream, then decreased in the middle, finally increased again in the downstream. This observation was similar with the previous studies (Meera and Nandan 2010). The mean average value of nutrients such as nitrate, nitrite and ammonia were $0.115 \pm 0.006,0.132 \pm 0.003$ and $0.376 \pm 0.04 \mathrm{mg} / 1$, respectively. The highest nutrients were found in Station 1 (upstream) and the lowest in Station 6 (down stream). This nutrient concentration pattern may be attributed to the point and nonpoint sources of pollution and erosion effects. Point source pollution is attributed to domestic wastewater discharged from upstream human settlements, whereas nonpoint source pollution is contributed by agricultural and livestock farms (Madramootoo et al. 1997).

Biomass: Distribution of zooplankton biomass fluctuated temporally and spatially (Figs 2 and 3). Station 6 showed maximum value of biomass in February, while Station 1 showed minimum value of biomass in October. Biomass was generally higher in the downstream than in the upstream. Biomass values varied among up, middle and downstream of the estuary during sampling months and stations (ranging from 0.365 to $0.642 \mathrm{~g}$ dry wt. $\mathrm{m}^{-3}$ ). 


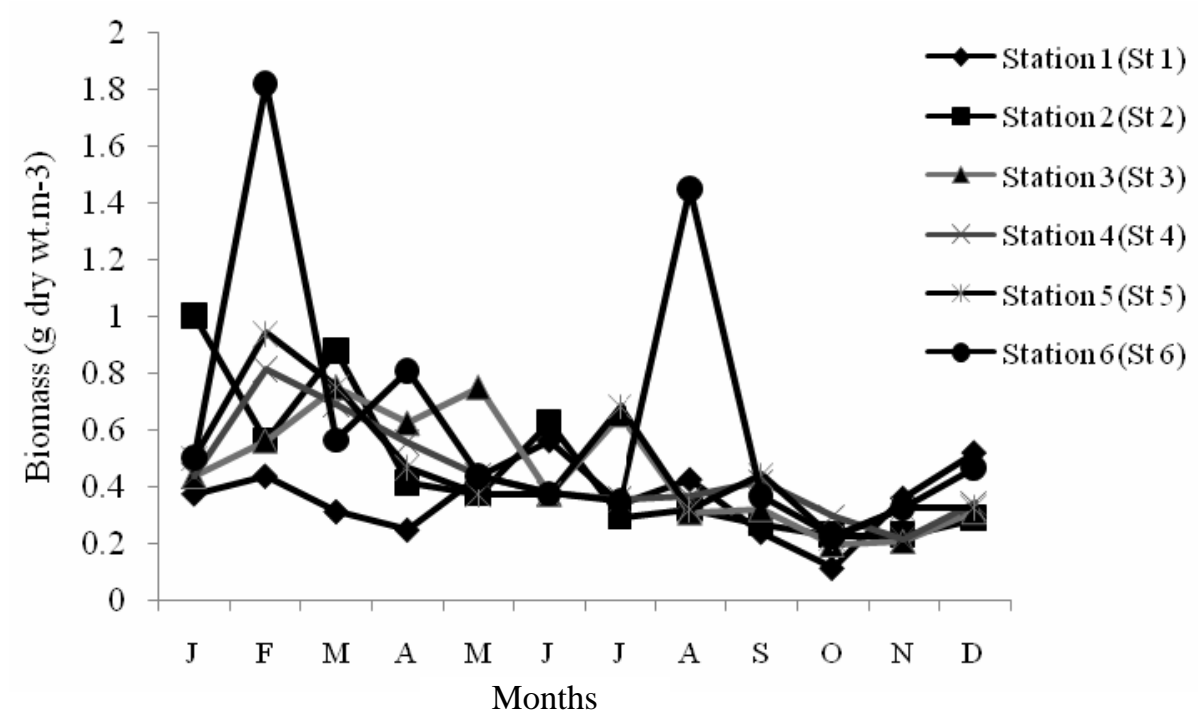

Fig. 2. Temporal distribution of zooplankton biomass from January to December, 2011.

During the study period a strong seasonal pattern of zooplankton biomass were observed. Both the highest and lowest values were recorded in wet season (Fig. 4).

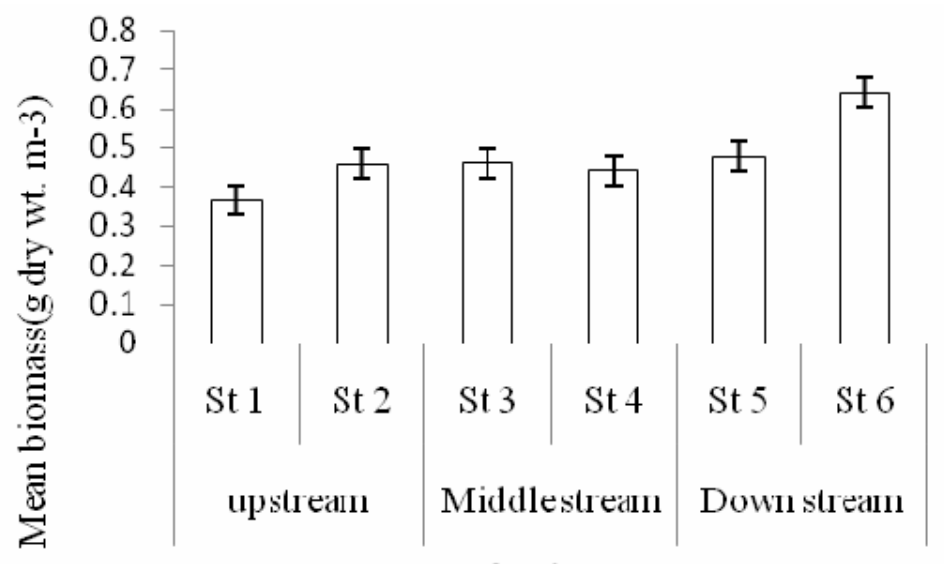

Stations

Fig. 3. Mean zooplankton biomass in the Merbok estuary (vertical bars represent the standard errors).

Zooplankton biomass during wet and dry season ranged from 0.34 to $0.66 \mathrm{~g}$ dry wt. $\mathrm{m}^{-3}$ and 0.39 and $0.62 \mathrm{~g}$ dry wt. $\mathrm{m}^{-3}$, respectively. The maximum biomass was found at Station 6 (downstream) and the minimum at Station 1(upstream) in both dry and wet season. The highly biomass concentration in the downstream area of the Merbok estuary may be contributed to the flushing of nutrients and organic particles by run off from the upstream area, presence of 
extensive mangrove vegetation along the middle stream and upstream. Previous study by Froneman (2001) observed similar pattern of results.

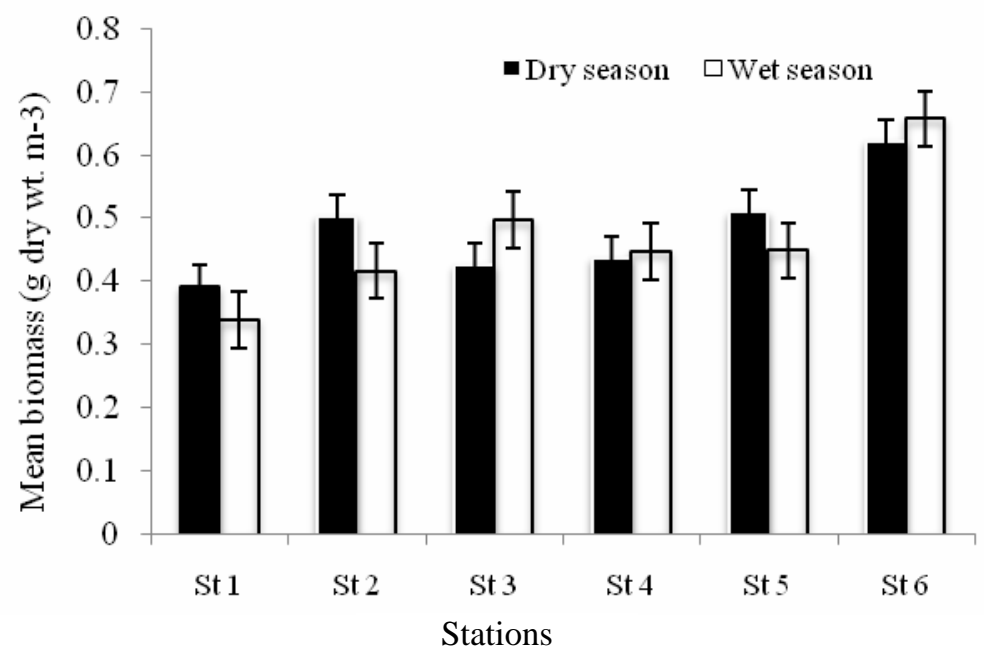

Fig. 4. Seasonal distribution pattern of zooplankton biomass at all sampling stations in Merbok estuary.

Kruskal-Wallis $\mathrm{H}$ test showed no significant difference $(\mathrm{p}>0.05)$ in biomass between sampling stations and seasons. However, Mann-Whitney $U$ test (Wilcoxon rank sum $\mathrm{W}$ test) showed significant difference $(\mathrm{p}<0.05)$ in biomass between the sampling months. The Wilcoxon $t$ test indicates that there was a significant difference in zooplankton biomass among the sampling stations and months $(z=-9.097, p<0.05)$. Results of Spearman's rank correlation analysis found that there were a significant correlation of biomass between month and station. Biomass was found positively correlated with salinity $(\mathrm{r}=0.175, \mathrm{p}<$ 0.05 ) whereas, negatively correlated with chlorophyll a $(\mathrm{r}=-0.285, \mathrm{p}<0.01)$. There was no correlation between temperature and biomass. On the other hand, there were a significant relationship between biomass and nutrients such as nitrate, nitrite and ammonia $(r=-0.270, r=-0.294$ and $r=-0.279, p<0.01)$.

In this study no significant seasonal variation were found between the sampling stations while, remarkable temporal variation was observed in zooplankton biomass. It could be concluded that temperature, salinity, food availability and nutrients of the estuary are critical parameter and play a vital role for spatial and temporal changes in zooplankton biomass.

\section{LITERATURE CITED}

APHA (American Public Health Association). 1991. Standard Methods for the Examination of Water and Waste Water. American Public Health Association Inc., New York . 
ADAM, V.D. 1991. Water and Wastewater Examination Manual. Lewis Publisher, Michigan.

DID (Department of Irrigation and Drainage). 1974. Hydrological Data: Streamflow Records, 1965-70. Ministry of Agricultural and Rural Development : Malaysia.

FRONEMAN, P. 2001. Seasonal changes in zooplankton biomass and grazing in a temperate estuary, South Africa. Estuarine Coastal Shelf Sci. 52: 543-553.

GRANGE, N. and ALLASON, B. 1995. The influence of freshwater inflow on the nature, amount and distribution of seston in estuaries of the Eastern Cape, South Africa. Estuarine Coastal Shelf Sci. 40: 403-420.

HARRIS, R. P. 2000. Zooplankton Methodology Manual. Academic Press, London.

ISA, M.M., BASRI, M.N.A., ZAWAWI, M.Z.M., YAHYA, K. and NOR, S.A.M. 2012. Length-weight Relationships of Some Important Estuarine Fish Species from Merbok Estuary, Kedah. Journal Natural Sci. and Res. 2: 8-17.

JERLING, H. and WOOLDRIDGE, T. 1991. Population dynamics and estimates of production for the calanoid copepod, Pseudodiaptomus hessei in a warm temperate estuary. Estuarine Coastal Shelf Sci. 33: 121-35.

KANIZ, F.; WAN MAZNAH,W.O. and MANSOR, M. I. 2012. Fluctuation of water quality parameters in Merbok Estuary, Kedah, Malaysia. In: Proceedings of the 3rd International Conference on Environmental Research and Technology, Penang. pp. 476-479.

KANIZ, F., WAN MAZNAH, W.O. and MANSOR, M.I. 2013. Limnology of Merbok estuary, Kedah, Malaysia. Bangladesh J. Zool. 41(1): 13-19.

KANIZ, F.. WAN MAZNAH, W.O. and MANSOR, M.I. 2015. Spatial variation of water quality parameters in a mangrove estuary. Intl. J. Environmental Sci. and Technol. 12: 2091-2102.

MADRAMOOTOO, C.A., JOHNSTON, W.R. and WILLARDSON, L.S. 1997. Management of agricultural drainage water quality. Food and Agriculture Organization. 13: 1-95.

MEERA, S. and NANDAN, S.B. 2010. Water quality status and primary productivity of Valanthakad Backwater in Kerala. Indian J. Marine Sci. 39(1): 105-113.

REZAI, H., YUSOFF, F., KAWAMURA, A., ARSHAD, A. and OTHMAN, B. 2003. Zooplankton Biomass in the Straits of Malacca. Indian J. Marine Sci. 32(3): 222-225.

SAHU, G., SATPATHY, K.K., MOHANTY, A.K. and SARKAR, S.K. 2012. Variations in community structure of phytoplankton in relation to physico-chemical properties of coastal waters, southeast coast of India. Indian J. Marine Sci. 41: 223-241.

STRICKLAND, J. and PARSONS, T. 1972. A Practical Handbook of Seawater Analysis, Fish. Res. Bd. Can. Bull. pp. 167: 310.

WICKSTEAD, J.H. 1965. An Introduction to the Study of Tropical Zooplankton. Hutchinson and Co. Ltd., London.

WOOLDRIDGE, T. 1999. Estuarine Zooplankton Community Structure and Dynamics. Estuaries of South Africa, Cambridge University Press, Cambridge. pp. 141-66.

(Manuscript received on 7 September, 2015; revised on 30 June, 2016) 